University of Nebraska - Lincoln

DigitalCommons@University of Nebraska - Lincoln

\title{
Where to sample? Ecological implications of sampling strata in determining abundance and impact of natural enemies of the coffee berry borer, Hypothenemus hampei
}

\author{
Juliana Jaramillo \\ Institute of Plant Diseases and Plant Protection \\ Adenirin Chabi-Olaye \\ International Center of Insect Physiology and Ecology \\ Christian Borgemeister \\ International Center of Insect Physiology and Ecology \\ Charles Kamonjo \\ International Center of Insect Physiology and Ecology \\ Hans-Michael Poehling \\ Institute of Plant Diseases and Plant Protection \\ See next page for additional authors \\ Follow this and additional works at: https://digitalcommons.unl.edu/usdaarsfacpub \\ Part of the Agricultural Science Commons
}

Jaramillo, Juliana; Chabi-Olaye, Adenirin; Borgemeister, Christian; Kamonjo, Charles; Poehling, HansMichael; and Vega, Fernando E., "Where to sample? Ecological implications of sampling strata in determining abundance and impact of natural enemies of the coffee berry borer, Hypothenemus hampei" (2009). Publications from USDA-ARS / UNL Faculty. 386.

https://digitalcommons.unl.edu/usdaarsfacpub/386

This Article is brought to you for free and open access by the U.S. Department of Agriculture: Agricultural Research Service, Lincoln, Nebraska at DigitalCommons@University of Nebraska - Lincoln. It has been accepted for inclusion in Publications from USDA-ARS / UNL Faculty by an authorized administrator of DigitalCommons@University of Nebraska - Lincoln. 


\section{Authors}

Juliana Jaramillo, Adenirin Chabi-Olaye, Christian Borgemeister, Charles Kamonjo, Hans-Michael Poehling, and Fernando E. Vega 


\title{
Where to sample? Ecological implications of sampling strata in determining abundance and impact of natural enemies of the coffee berry borer, Hypothenemus hampei
}

\author{
Juliana Jaramillo $^{\mathrm{a}, \mathrm{b}, *}$, Adenirin Chabi-Olaye ${ }^{\mathrm{b}}$, Christian Borgemeister ${ }^{\mathrm{b}}$, \\ Charles Kamonjo ${ }^{\mathrm{b}}$, Hans-Michael Poehling ${ }^{\mathrm{a}}$, Fernando E. Vega ${ }^{\mathrm{c}}$ \\ a Institute of Plant Diseases and Plant Protection, Leibniz Universität Hannover, Herrenhäuser Strasse 2, 30419 Hannover, Lower Saxony, Germany \\ ${ }^{\mathrm{b}}$ International Center of Insect Physiology and Ecology (icipe), P.O. Box 300772-00100 Nairobi, Kenya \\ ' Sustainable Perennial Crops Laboratory, United States Department of Agriculture, Agricultural Research Service, Building 001, Beltsville, MD 20705, USA
}

\section{A R T I C L E I N F O}

\section{Article history:}

Received 8 September 2008

Accepted 16 December 2008

Available online 25 December 2008

\section{Keywords:}

Hyopthenemus hampei

Coffee berry borer

Coffee

Biological control

Parasitoid

Prorops nasuta

Aphanogmus

Hyperparasitoid

Cultural control

IPM

\begin{abstract}
A B S T R A C T
Several parasitoids of African origin have been introduced to coffee producing areas of the Americas and Asia as biological control agents of the coffee berry borer (CBB) Hypothenemus hampei (Coleoptera: Curculionidae). These parasitoids have become established in the field but their effect on the CBB has been limited. A two-year field study in Western Kenya has found Prorops nasuta (Hymenoptera: Bethylidae) to be the predominant parasitoid emerging from CBB-infested coffee berries collected on coffee trees or from the ground. $P$. nasuta comprises more than $75 \%$ of the total natural enemies collected. The density of $P$. nasuta was $90 \%$ higher in the berries collected from the ground than from the trees. Its hyperparasitoid, Aphanogmus sp. (Hymenoptera: Ceraphronidae), also emerged from both type of berries. Across the two seasons, the average $P$. nasuta density per berry was 18-35 times higher than that of Aphanogmus sp. Throughout the two years sampled, significantly higher numbers of $P$. nasuta and Aphanogmus sp. occurred between February and March, which coincides with the beginning of the rainy season. Higher numbers of live $\mathrm{CBB}$ females were recorded in berries collected from the trees. Nevertheless, mortality of adult CBB was considerably higher from January to March and started to decrease from April onwards. The possibly negative effects of cultural control practices in Latin America which include the removal of berries fallen to the ground on biological control of $\mathrm{CBB}$ are discussed, and the use of screened collection devices for these berries which would permit the release of parasitoids but prevent escape of the pest is proposed.
\end{abstract}

(c) 2008 Elsevier Inc. All rights reserved.

\section{Introduction}

Endemic to Central Africa, the coffee berry borer Hypothenemus hampei (Ferrari) (Coleoptera: Curculionidae) is the most devastating insect pest of commercial coffee worldwide (Le Pelley, 1973; Damon, 2000; Jaramillo et al., 2006). Female insects bore galleries in the berry where they oviposit up to 200 eggs, causing qualitative and quantitative losses through larval feeding of the endosperm. The cryptic nature of CBB inside the berry, combined with a skewed sex ratio favoring females (10:1) and sibling mating inside the berry makes this insect quite difficult to control. Reported infestation levels of the pest can be extremely high, e.g., $60 \%$ in Colombia, 58-85\% in Jamaica, 50-90\% in Malaysia, and 60\% in Mexico (Vega, 2004). Due to the insects' concealed nature, biological

\footnotetext{
* Corresponding author. Address: Institute of Plant Diseases and Plant Protection, Leibniz Universität Hannover, Herrenhäuser Strasse 2, 30419 Hannover, Lower Saxony, Germany. Fax: +254208561690.

E-mail address: jjaramillo@icipe.org (J. Jaramillo).
}

control is the most promising management option against $H$. hampei.

Previous explorations for natural enemies of CBB in Africa have revealed the presence of various parasitoids, including the braconid Heterospilus coffeicola Schmiedeknecht, which was first reported by Hargreaves (1926) in Uganda. However, so far no viable rearing protocols have been developed for this wasp, limiting its use in biological control programs (Murphy et al., 2001). In addition, two bethylid parasitoids of CBB have been discovered: Cephalonomia stephanoderis Betrem and Prorops nasuta Waterston originating from Ivory Coast (Ticheler, 1961) and Uganda (Hempel, 1934), respectively. These bethylids are larval-pupal ectoparasitoids of CBB and usually prey on females and eggs (Pérez-Lachaud et al., 2002; Infante et al., 2005). A fourth parasitoid species, the eulophid Phymastichus coffea LaSalle was recorded first in Togo in 1987 (Borbón-Martinez, 1989).

Cephalonomia stephanoderis and $P$. nasuta have been introduced to coffee growing areas in the Americas (Barrera et al., 1990; Baker, 1999) and to India (Duque and Baker, 2003). In the Americas they 
are presently being used in an integrated pest management (IPM) program combined with entomopathogenic fungi like Beauveria bassiana (Balsamo) Vuillemin (Ascomycota: Hypocreales), trapping, and cultural control. Although, $C$. stephanoderis and P. nasuta became established in the all release countries in the Americas, levels of parasitism in $H$. hampei field populations rarely exceed 5\% (Quintero et al., 1998; Baker, 1999; Infante et al., 2001).

The cultural control component of the CBB IPM program in the Americas involves the complete removal of all ripe and over-ripe berries after the harvest and during the inter-harvest period thus reducing vital sources of re-infestations. Rigorous collection of berries from the trees and from the ground, termed 'Re-Re' in Spanish for 'Recolección' and 'Repase' (harvesting of berries and immediately thorough re-collection of remaining berries in the same field), can substantially reduce infestations of the pest in the field for two reasons: (i) immigrating CBB females from populations outside the field will not find suitable berries for oviposition, thus breaking the infestation cycle of the pest and (ii) dry berries harboring CBBs are removed, thereby reducing the $H$. hampei source population of the field/plantation (Bustillo et al., 1998). It is estimated that $89 \%$ of the total CBB management costs go to personnel due to this laborious cultural control practice (Duque and Baker, 2003). In spite of its cost, an analysis of the different CBB IPM options in Colombia concluded that cultural control is the most important and widely used component (Aristizabal et al., 2002; Benavides et al., 2002).

The objective of this study was to evaluate the seasonal ecology and dynamics of CBB bethylid parasitoids in a coffee growing area of Kenya, over two fruiting periods, in coffee berries collected from the trees and in coffee berries that had fallen to the ground.

\section{Materials and methods}

Parasitoids associated with CBB were sampled from October 2006 to September 2008 in the Kisii area of Western Kenya $\left(00^{\circ}\right.$ $25^{\prime} \mathrm{S}, 34^{\circ} 28^{\prime} \mathrm{E}, 1510 \mathrm{~m}$ above sea level [masl]). A plantation consisting of 2000 trees of Coffea arabica L. (var. Ruiru 11) was selected for the study. Climatic data, i.e. monthly values of mean, max and min temperature, relative humidity $(\mathrm{RH})$ and precipitation were obtained from the Kenyan Agriculture Research Institute (KARI).

Samples of CBB-infested coffee berries both from the trees and the ground, i.e. the litter strata, were collected at 2-3 weeks intervals for 2006 and 2007 and weekly during 2008. Between 100 and 150 trees were sampled randomly at each evaluation date, collecting as many CBB-infested berries on the branches and from the ground as possible.

The coffee berries were surface sterilized in the laboratory to reduce fungal contamination during the period in which berries were to be sampled for parasitoid emergence. The sterilization procedure (Pérez et al., 2005) consists of washing the berries with detergent for $15 \mathrm{~min}$, rinsing with tap water, then dipping in a $2 \%$ sodium hypochlorite solution for $10 \mathrm{~min}$, rinsing again with sterile distilled water, thereafter soaking in a $2 \%$ potassium sorbate solution and finally rinsing with sterile distilled water. Subsequently the coffee berries were allowed to dry at room temperature. After surface sterilization, the berries were placed in square plastic containers $(40 \times 40 \times 20 \mathrm{~cm})$ with perforated lids $(55 \mathrm{~mm} \mathrm{dia})$, covered with mesh to avoid the escape of the parasitoids. Each container was filled with a $3 \mathrm{~cm}$ layer of a mixture of plaster of Paris and activated charcoal to maintain the humidity and prevent the desiccation of the berries (Jaramillo et al., 2009), thus allowing to record the emergence of the natural enemies for periods of up to 90 days after each sampling date. The interior of the containers was watered every 3 days to maintain the humidity inside the container; containers were kept at room temperature (ca. $25 \pm 2{ }^{\circ} \mathrm{C}$, $70 \% \pm 5 \% \mathrm{RH}$ and L12:D12 photoperiod). The berries were cleaned every 2 days to remove the CBB frass. Emergence of parasitoids was assessed daily, and emerged parasitoids were recorded and individually transferred to $0.5 \mathrm{ml}$ Eppendorf ${ }^{\circledR}$ tubes containing 95\% ethanol. During 2008, in addition to recording the emergence of parasitoids a sub-sample of 100 berries was taken from each sampling date once parasitoids ceased to emerge; these berries were then dissected under the stereomicroscope $(10 \times)$, in search for natural enemies that had not emerged from the coffee berries. Specimens were shipped to and then identified at the Systematic Entomology Laboratory, United States Department of Agriculture, Agricultural Research Service (USDA-ARS), in Beltsville, Maryland, USA.

\subsection{Statistical analyses}

Data on abundance and emergence of parasitoids are presented separately for berries collected on the ground and in the trees. Shannon's diversity index (Shannon, 1948) was calculated individually for parasitoids emerging from berries from the tree and ground strata for all sampling months, using the following formula:

$$
\text { (1) } H^{\prime}=-\sum_{i=1}^{s} p_{i} \ln p_{i}
$$

where $S$ is the number of species, and $p_{i}$ is the relative abundance of each species, calculated as the proportion of individuals of a given species to the total number of individuals in the community. Shannon diversity index increases as the number of different species increases and/or the proportional distribution of individuals among species becomes more equitable. For a given number of species, the maximum value of the Shannon index is reached when there are similar proportions of all species.

A covariance analysis was performed, using the GLM procedure of SAS (SAS Institute Inc., 1999) to investigate the effects of sampling months and coffee berry strata on the abundance (average insect per berry per sampling month) of $P$. nasuta and Aphanogmus sp. (Hymenoptera: Ceraphronidae), where the total number of berries collected was used as a co-variable. The estimates of parameters that contribute to the abundance of the parasitoid and its hyperparasitoid were calculated. Averages of P. nasuta and Aphanogmus sp. per berry per month were log transformed prior to analysis. For each parameter that contributed to the abundance, the $t$-value was calculated and the significant level was set at 0.05 .

Dissection data were analyzed by means of analysis of variance ANOVA, using the general linear model (PROC GLM) of SAS (SAS Institute Inc., 1999). In case the ANOVAs yielded significant F-values, means were compared using Tukey's test (HSD).

Percentage parasitism (Van Driesche, 1983) was calculated separately for the samples for the tree and ground berry samples using the following formula:

$$
\begin{aligned}
\% \text { Parasitism }= & \text { (emergence of parasitoids per } 100 \text { berries } \\
& + \text { parasitoid immature stages and adults found } \\
& \text { during dissections per } 100 \text { berries }) / \\
& \text { (decapitated CBB females + parasitoid cocoons). }
\end{aligned}
$$

\section{Results}

\subsection{Parasitoid species complex}

Emergence of parasitoids was recorded from a total of 32,780 berries collected from the trees and 36,729 berries from the litter (ground) strata, between October 2006 and September 2008. An 
additional 3842 berries sampled in 2008 were dissected for CBB life stages and natural enemies. In total 333 parasitoid/hyperparasitoid specimens were collected from berries harvested from the trees and 10,409 emerged from the ground strata samples. All of these parasitoids/hyperparasitoids are considered to be associated with CBB (Table 1). Across sampling periods, eight species were collected (four species from the trees vs. seven from the ground strata) resulting in a Shannon index of 0.73 for tree coffee berries and 0.6 for the ground strata.

For coffee berries collected from the trees, $P$. nasuta was the dominant parasitoid species with $71.5 \%$ of the total parasitoid emergence, followed by unidentified parasitoid sample \#57 (24.0\%), Tapinoma sp. (Hymenoptera: Formicidae: Dolichoderinae) sample \#111 (2.7\%), Aphanogmus sp. (1.2\%), P. coffea (0.3\%) and C. stephanoderis $(0.3 \%)$.

From the coffee berries that were collected on the ground, the most dominant parasitoid was again $P$. nasuta accounting for $82.2 \%$ of the total emergence, followed by its hyperparasitoid Aphanogmus sp. (12.7\%), unidentified parasitoid sample \#57 (4.4\%), unidentified parasitoid sample \#54 (0.1\%), P. coffea (0.1\%), P. near schedli $(0.1 \%)$, C. stephanoderis (0.02\%) and Goniozus sp. (Hymenoptera: Bethylidae) (0.06\%).

\subsection{Relative abundance of CBB parasitoid species over the sampling periods}

Fig. 1 shows the abundance of the CBB parasitoid complex over time for the trees and ground strata. The dominant species were $P$. nasuta and its hyperparasitoid Aphanogmus sp. For berries collected from the ground, considerably higher numbers of species were recorded during the first months of 2007 compared to the same period in 2008. Tapinoma sp. was only collected from tree berries between June and July 2007. Aphanogmus sp. was collected in different months on ground berries and was only recorded one time in August 2007 on tree berries.

Table 1

Most abundant species recovered from coffee berries collected on the ground and from coffee trees.

\begin{tabular}{|c|c|c|c|}
\hline Species & Habit & $\begin{array}{l}\text { Place of } \\
\text { collection }\end{array}$ & $N$ \\
\hline \multicolumn{4}{|l|}{ Hymenoptera } \\
\hline \multicolumn{4}{|l|}{ Bethylidae } \\
\hline \multirow{2}{*}{$\begin{array}{l}\text { Cephalonomia } \\
\text { stephanoderis }\end{array}$} & \multirow{2}{*}{$\begin{array}{l}\text { Primary CBB parasitoid (Ticheler, } \\
\text { 1961) }\end{array}$} & Ground & 2 \\
\hline & & Tree & 1 \\
\hline \multirow[t]{2}{*}{ Prorops nasuta } & \multirow{2}{*}{$\begin{array}{l}\text { Primary CBB parasitoid (Hargreaves, } \\
1926 \text { ) }\end{array}$} & Ground & 8180 \\
\hline & & Tree & 240 \\
\hline \multirow[t]{2}{*}{ Goniozus sp. } & \multirow[t]{2}{*}{ Possible new CBB parasitoid } & Ground & 6 \\
\hline & & Tree & 0 \\
\hline \multicolumn{4}{|l|}{ Ceraphronidae } \\
\hline \multirow{2}{*}{ Aphanogmus sp. } & \multirow{2}{*}{$\begin{array}{l}\text { P. nasuta hyperparasitoid (Jaramillo } \\
\text { and Vega, 2009) }\end{array}$} & Ground & 1342 \\
\hline & & Tree & 4 \\
\hline \multicolumn{4}{|l|}{ Eulophidae } \\
\hline \multirow{2}{*}{$\begin{array}{l}\text { Phymastichus } \\
\text { coffea }\end{array}$} & \multirow{2}{*}{$\begin{array}{l}\text { Primary CBB parasitoid (Borbon, } \\
\text { 1989) }\end{array}$} & Ground & 16 \\
\hline & & Tree & 1 \\
\hline \multicolumn{4}{|l|}{ Formicidae } \\
\hline \multirow[t]{2}{*}{ Tapinoma sp. } & \multirow{2}{*}{ Possible CBB predator } & Ground & 0 \\
\hline & & Tree & 9 \\
\hline \multicolumn{4}{|l|}{ Pteromalidae } \\
\hline \multirow{2}{*}{$\begin{array}{l}\text { Pachycrepoideus } \\
\text { near schedli }\end{array}$} & \multirow[t]{2}{*}{ Possible CBB parasitoid (OILB, 1971) } & Ground & 13 \\
\hline & & Tree & 0 \\
\hline \multicolumn{4}{|l|}{ Others } \\
\hline \multirow[t]{2}{*}{ Sample 54} & \multirow[t]{2}{*}{ Under identification } & Ground & 12 \\
\hline & & Tree & 0 \\
\hline \multirow[t]{2}{*}{ Sample 57} & \multirow[t]{2}{*}{ Under identification } & Ground & 430 \\
\hline & & Tree & 0 \\
\hline
\end{tabular}

3.3. . Dynamics of P. nasuta and its hyperparasitoid Aphanogmus sp. on tree and ground berries

The analysis of covariance using the total berries as covariate indicated that the abundance of $P$. nasuta and its hyperparasitoid Aphanogmus sp. varied significantly with coffee berry strata $\left(F_{1,97}=40.28, P<0.0001\right.$ and $F_{1,97}=24.94, P<0.0001$ for $P$. nasuta and Aphanogmus sp., respectively). Their occurrence was significantly higher on ground compared to tree berries (Table 2). Likewise, time of the year had a significant impact on numbers of $P$. nasuta and Aphanogmus sp. $\left(F_{1,97}=6.03, P<0.0001\right.$ and $F_{1,97}=5.82, P<0.0001$ for $P$. nasuta and Aphanogmus sp., respectively). Across the two sampling years and coffee berry strata, significantly higher numbers of $P$. nasuta and Aphanogmus sp. occurred between February and March (Table 2).

\subsubsection{Ground}

During the three sampling months in 2006, low numbers of P. nasuta and Aphanogmus sp. were recorded (Fig. 2). The average density per infested berry increased in early January 2007 for P. nasuta, and for Aphanogmus sp. peaked during February and March of the same year (Fig. 2). A second peak was observed in February 2008 for both P. nasuta and Aphanogmus sp. Across the seasons, the average $P$. nasuta density per berry was 18-35 times higher than that of Aphanogmus sp. (Fig. 2).

\subsubsection{Tree}

Densities of both P. nasuta and Aphanogmus sp. were relatively lower in berries sampled from the trees compared to the ground stratum ( $<0.08$ insect per berry) (Fig. 3). A first peak for P. nasuta was observed in May 2007, a second in December 2007 and the last one in March 2008.

\subsection{Dissection of coffee berries}

Dissections of the coffee berries were carried out only in 2008 after determining a trend in the emergence of the parasitoids. Tree or ground strata and the month of collection had a significant effect on the numbers of $\mathrm{CBB}$ immature stages $\left(F_{1}, \quad 3662=10.21\right.$, $P=0.0014)\left(F_{7,3662}=39.5, P<0.0001\right)$, total numbers of $\mathrm{CBB}$ females $\left(F_{1}, 3662=14.8, P<0.0001\right)\left(F_{7}, 3662=38.7, P<0.0001\right)$, females found live $\left(F_{1}, \quad 3662=30.0, \quad P<0.0001\right) \quad\left(F_{7}, \quad 3662=11.4\right.$, $P<0.0001)$, dead $\left(F_{1}, 3662=138.7, P<0.0001\right) \quad\left(F_{7}, \quad 3662=53.7\right.$, $P<0.0001)$ and CBB female mortality $\left(F_{1,3662}=347.5, P<0.0001\right)$ $\left(F_{7,3662}=79.1, P<0.0001\right)$. Likewise the interaction sampling strata by month of collection was always significant except in the case of CBB immature stages $\left(F_{7,3662}=0.52, P=0.8168\right)$ (Figs. $\left.4-6\right)$.

In general, a high percentage of berries were attacked by $\mathrm{CBB}$ and the infestation ranged from $60-91 \%$ and $44-84 \%$ for ground and tree berries, respectively. However, the total numbers of CBB females per berry was low, ranging from 2.9 in February to 9.9 in March for ground berries (Fig. 5a) and between 2.4 in May and 7.6 in March. CBB females that were found alive during the dissections were higher in tree compared to ground berries (Fig. 5b). The number of immature stages started to increase from February reaching the maximum number in June (Fig. 4). The mortality of CBB was considerably higher during January, February and March and started to decrease from April onwards (Fig. 6). This reduction of CBB mortality coincided with a decrease in numbers of $P$. nasuta emerging from the samples (Figs. 2 and 3).

Hardly any life stages of $P$. nasuta were found in tree berries. However, the sampling strata and month of collection of the coffee berries had an effect on the numbers for cocoons $\left(F_{4,1351}=16.6\right.$, $P<0.0001)$, for $P$. nasuta live $\left(F_{4,1351}=12.9, P<0.0001\right)$, and for $P$. nasuta dead $\left(F_{4}, 1351=26.4, P<0.0001\right)$. In ground berries, be- 


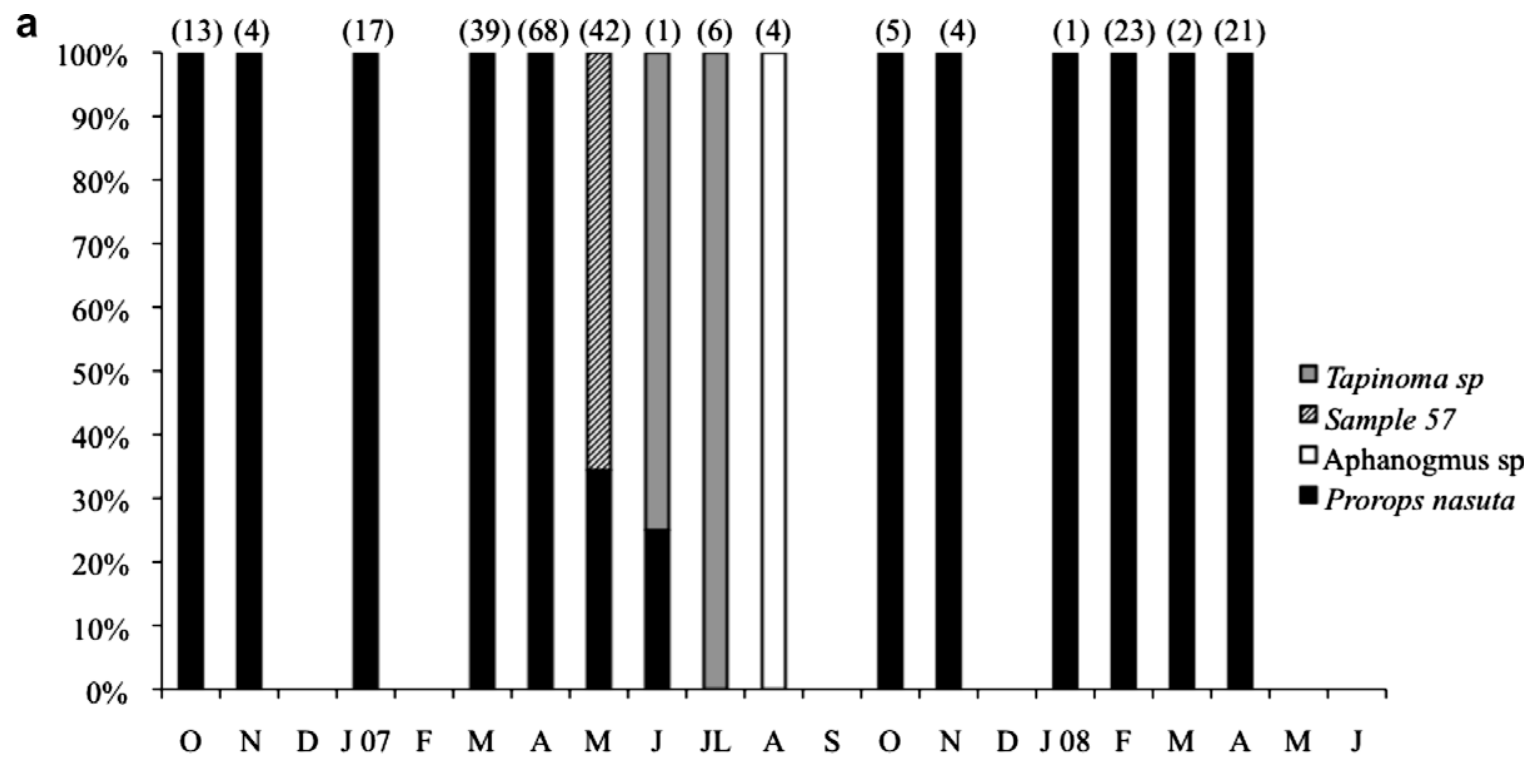

06

Trees

Time

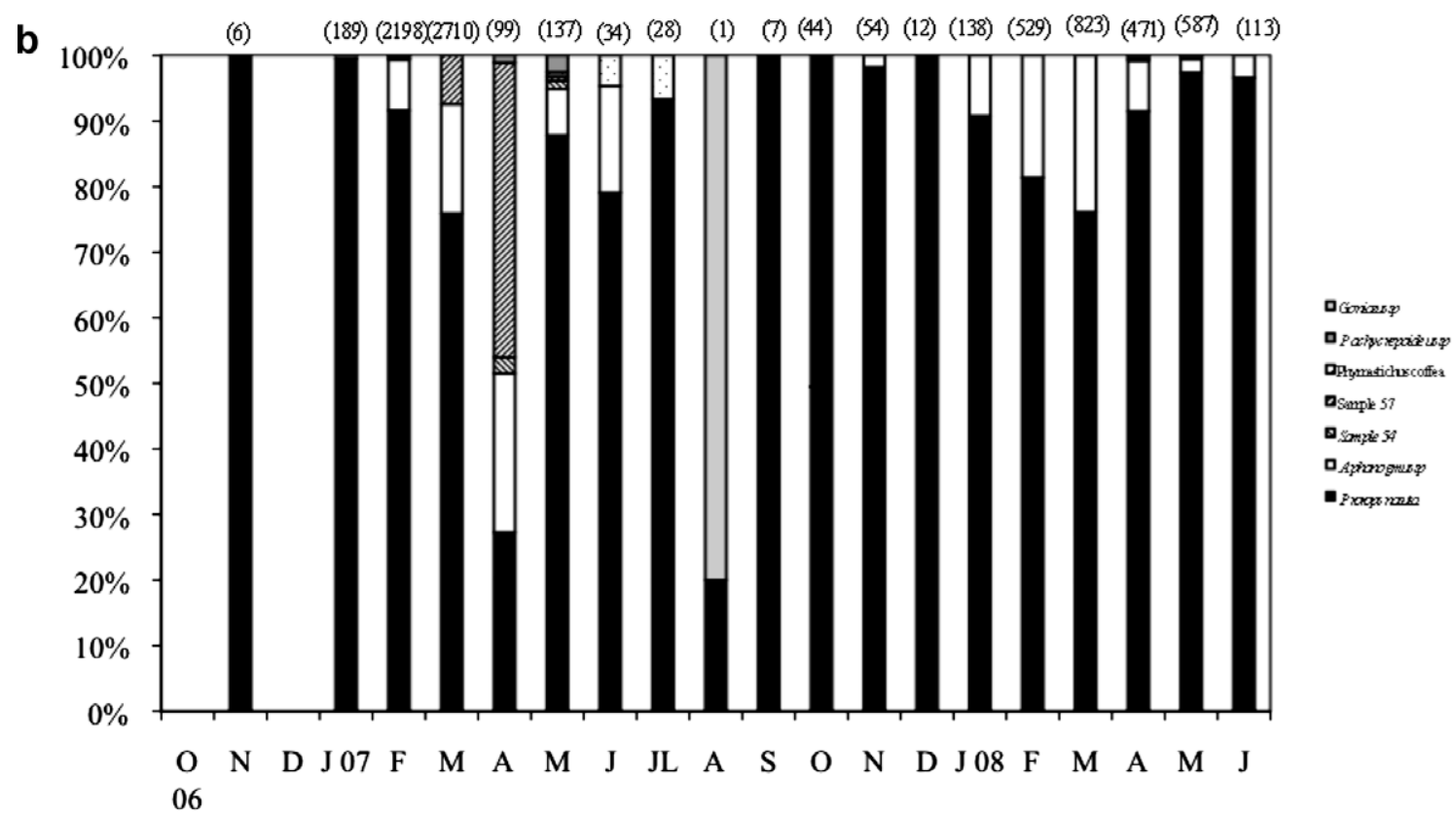

Ground

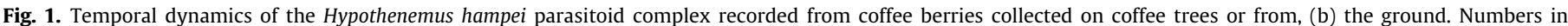

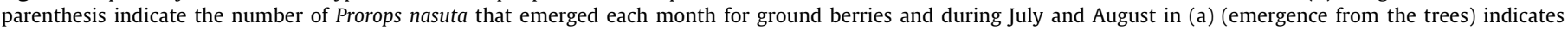
numbers of Tapinoma sp. and Aphanogmus sp., respectively.

tween 0.08 and 0.66 dead and alive adult P. nasuta and 0.26 to 1.84 cocoons of the parasitoid were found inside a single berry. Moreover, no Aphanogmus sp. individuals were detected when dissecting berries collected on the ground and in the trees.

\subsection{Percentage of parasitism}

In ground berries, parasitism of CBB by $P$. nasuta was $17.8 \%$, $49.1 \%, 21.2 \%, 31.0 \%$, and $47.1 \%$ for the months of January, February, March, April and May 2008, respectively. Only four $P$. nasuta adults and no cocoons were found after dissecting the berries collected from trees; therefore levels of parasitism could not be estimated for this stratum.

\section{Discussion}

Two years of intensive sampling in a coffee plantation in Western Kenya revealed a surprisingly low diversity of CBB parasitoids, as illustrated by the low Shannon index values. Apart from the bethylid parasitoid $P$. nasuta and its ceraphronid hyperparasitoid Aphanogmus sp. (Jaramillo and Vega, 2009), all other known parasitoids of $H$. hampei were either absent or recorded in very low 
Table 2

Covariance analysis of the effect of sampling months and coffee berry sampling strata on the abundance of Prorops nasuta and its hyperparasitoid Aphanogmus sp.

\begin{tabular}{|c|c|c|c|c|c|c|c|c|}
\hline \multirow[t]{2}{*}{ Variables } & \multicolumn{4}{|c|}{ Log (mean Prorops nasuta per berry) } & \multicolumn{4}{|c|}{ Log (mean Aphanogmus sp. per berry) } \\
\hline & Estimate & SE & $t$-Value & $P$-Value & Estimate & SE & $t$-Value & $P$-Value \\
\hline \multicolumn{9}{|l|}{ Months } \\
\hline January & 0.0425 & 0.0284 & 1.5000 & 0.1378 & 0.0061 & 0.0073 & 0.8300 & 0.4083 \\
\hline February & 0.1249 & 0.0293 & 4.2700 & 0.0001 & 0.0237 & 0.0075 & 3.1300 & 0.0023 \\
\hline March & 0.1061 & 0.0287 & 3.7000 & 0.0004 & 0.0320 & 0.0074 & 4.3200 & 0.0001 \\
\hline April & 0.0222 & 0.0333 & 0.6700 & 0.5066 & 0.0093 & 0.0086 & 1.0800 & 0.2814 \\
\hline May & 0.0166 & 0.0316 & 0.5300 & 0.6002 & 0.0007 & 0.0081 & 0.0900 & 0.9306 \\
\hline June & 0.0016 & 0.0304 & 0.0500 & 0.9570 & 0.0007 & 0.0079 & 0.0900 & 0.9249 \\
\hline July & 0.0056 & 0.0292 & 0.1900 & 0.8492 & 0.0000 & 0.0075 & 0.0000 & 0.9994 \\
\hline August & -0.0020 & 0.0298 & 0.0700 & 0.9457 & 0.0000 & 0.0077 & 0.0000 & 0.9962 \\
\hline September & 0.0000 & - & - & - & 0.0000 & - & - & - \\
\hline October & -0.0026 & 0.0272 & 0.1000 & 0.9238 & -0.0007 & 0.0070 & 0.0900 & 0.9250 \\
\hline November & -0.0001 & 0.0297 & 0.0000 & 0.9986 & 0.0001 & 0.0077 & 0.0100 & 0.9932 \\
\hline December & -0.0016 & 0.0294 & 0.0500 & 0.9570 & 0.0000 & 0.0076 & 0.0000 & 0.9977 \\
\hline Ground strata & 0.0706 & 0.0111 & 6.3400 & 0.0001 & 0.0143 & 0.0029 & 4.9900 & 0.0001 \\
\hline Tree strata & 0.0000 & - & - & - & 0.0000 & - & - & - \\
\hline Total berries & 0.0000 & 0.0000 & 0.0900 & 0.9291 & 0.0000 & 0.0000 & 0.0200 & 0.9808 \\
\hline Intercept & -0.0264 & 0.0217 & 1.2200 & 0.2271 & -0.0072 & 0.0056 & 1.2800 & 0.2023 \\
\hline
\end{tabular}

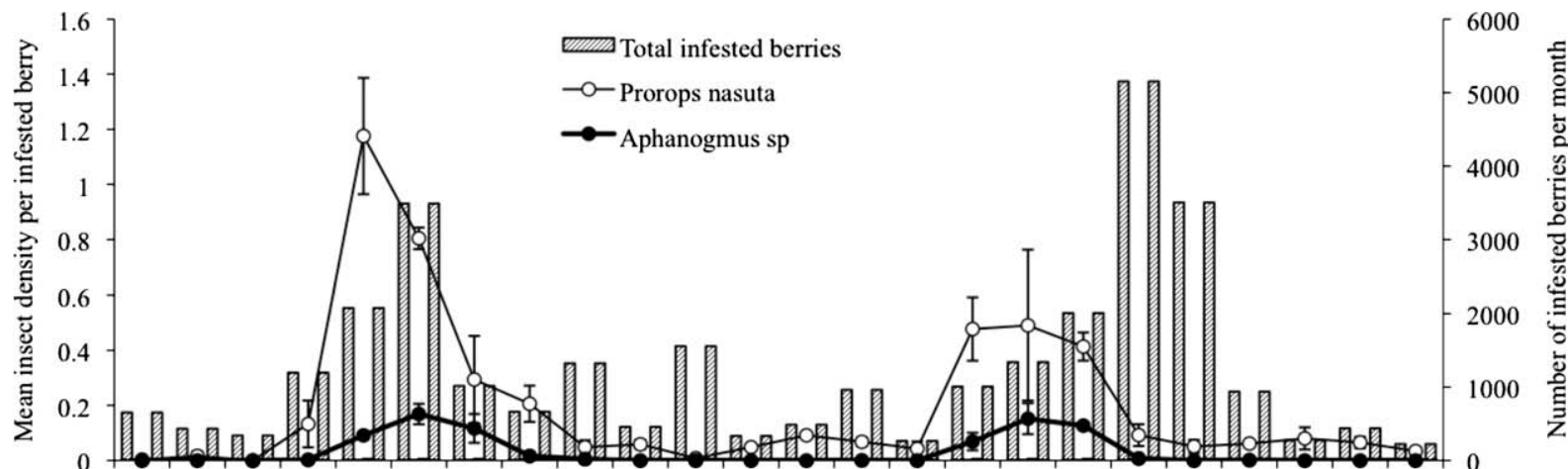

Oct Nov Dec Jan Feb Mar Apr May Jun Jul Aug Sep Oct Nov Dec Jan Feb Mar Apr May Jun Jul Aug Sep 06 07

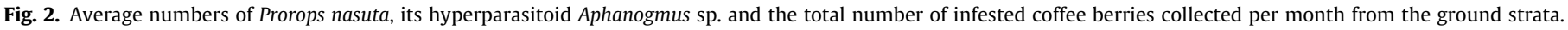

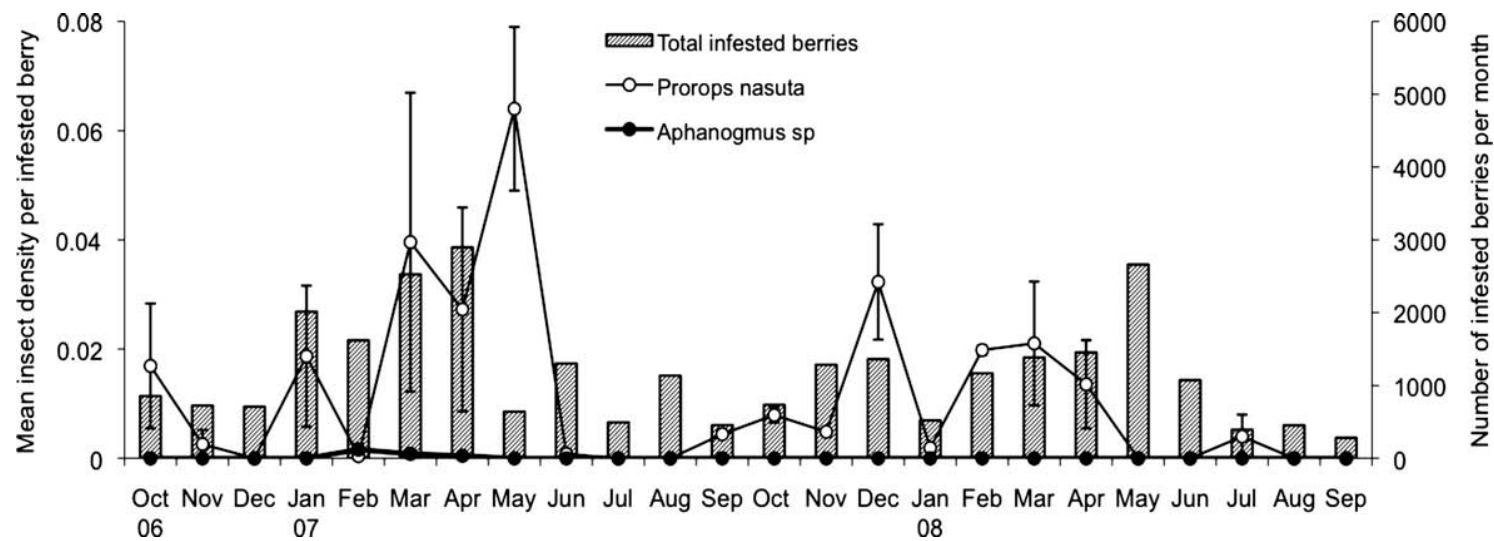

Fig. 3. Average numbers of Prorops nasuta, its hyperparasitoid Aphanogmus sp. and the total number of infested coffee berries collected per month from the tree strata.

numbers. For instance the eulophid $P$. coffea was virtually nonexistent in our sampling area during the two years of the study. Yet the original collections of the wasps that were subsequently introduced to Colombia as part of a classical biological control program for CBB were carried out exactly in the same area of Western Kenya where all data for this study was gathered (Baker, 1999). It was also striking that the braconid $H$. coffeicola was never found during our two years of sampling. In a similar study in neighboring Ugan- da, Hargreaves (1926) reported $H$. coffeicola and $P$. nasuta as the two predominant natural enemies of the CBB.

One might argue that the low diversity of natural enemies recorded in our study is due to the fact that we restricted our sampling to one coffee plantation only. Yet the focus of this research was to elucidate the seasonal dynamics of natural enemies of $\mathrm{CBB}$, and hence we sampled throughout two entire fruiting seasons, i.e. from blossoming to harvest. In contrast pre- 


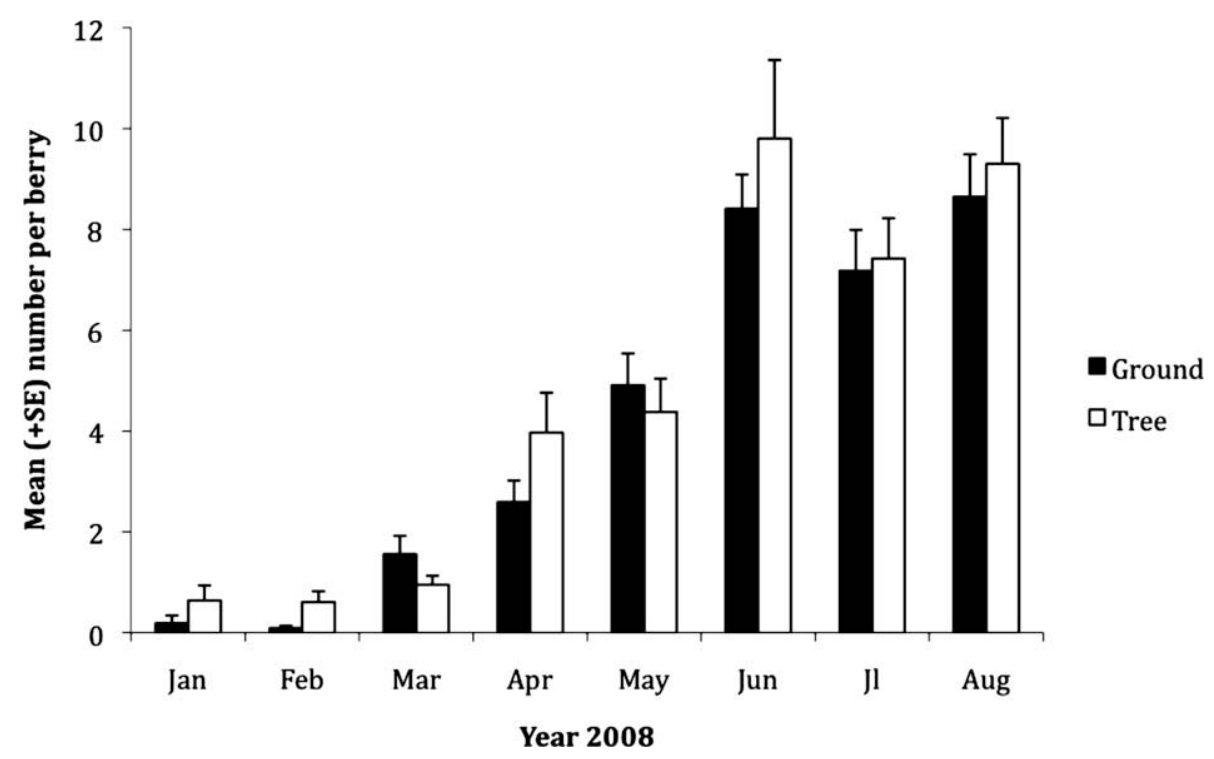

Fig. 4. Mean (+SE) numbers of immature stages of Hypothenemus hampei inside coffee berries collected on coffee trees or on the ground over time.

vious studies followed more a survey approach, often resulting in only snapshot-like information on the diversity of natural enemies of CBB. Thus despite the fact that we sampled only in one plantation we were able to record with Aphanogmus sp. a previously unknown hyperparasitoid of $P$. nasuta (Jaramillo and Vega, 2009), and discover a new specialized predator of CBB (Jaramillo, unpublished results).

Vega et al. (1999) recorded C. stephanoderis as the most prevalent CBB parasitoid in Togo. Out of the 10,342 CBB parasitoids identified in the present study only two specimens of $C$. stephanoderis were obtained. According to Ticheler (1961) and Hargreaves (1935), C. stephanoderis and P. nasuta are the dominant parasitoids of $H$. hampei in West and East Africa, respectively.

We recorded one major peak in emergence (February to May) for $P$. nasuta in our study area; this is in agreement with observations by Hargreaves (1926) in Uganda, where one peak was also reported in this country, although it occurred later in the year. Aphanogmus sp., a hyperparasitoid of $P$. nasuta, started to appear approximately one month later. Around $10 \%$ of the P. nasuta cocoons were hyperparasitized, and between two and three Aphanogmus sp. adults on average emerged from the host cocoons (Jaramillo and Vega, 2009).

An additional explanation for the low biodiversity of CBB parasitoids in our study sites might be the type of coffee plantation we sampled. Despite the organic production system used, the plantation was not shaded and was surrounded by other crops. Intensification of the coffee system has been reported to lead to low insect biodiversity (Perfecto et al., 2003; Richter et al., 2007).

Why has $P$. nasuta, in spite of being the key natural enemy of CBB in East Africa, as indicated by our data for Western Kenya and by Hargreaves (1926) for Uganda, been such an ineffective biological control agent in the Americas? A recent study from Colombia reported $73 \%$ establishment of $P$. nasuta in coffee farms but parasitism levels of only 0.25-19.5\% (Maldonado, 2007). Similarly, reports from Infante (1998) in Mexico suggest that $P$. nasuta is only able to maintain high populations in the field if there are multiple releases. Previous attempts to resolve this riddle focused on the potentially negative interactions between $C$. stephanoderis, $P$. nasuta and $C$. hyalinipennis Ashmead, the latter being indigenous to the new world (Pérez-Lachaud et al., 2002, 2004; Batchelor et al., 2005, 2006). However, Batchelor et al.
(2006) has recently suggested that $P$. nasuta should be the most effective biological control agent of CBB due to its comparatively superior emergence rate and female offspring production. They also concluded that the failure of $P$. nasuta as a biological control agent in Mexico is hence not likely to be due to competitive interactions with the other bethylids.

In this study, out of the 8893 individual $P$. nasuta collected, only $2.7 \%$ emerged from berries picked from the trees, whereas the remaining $97.3 \%$ originated from berries that were collected on the ground. What is the importance of these findings for the control of $\mathrm{CBB}$ in the Americas? Presently, the most successful and widely adopted non-chemical control strategy against CBB in several Latin American countries promotes the complete removal and subsequent processing of all CBB-infested coffee berries from the trees as well as those that have fallen to the ground (Aristizabal et al., 2002), as originally proposed by Bergamin (1944b). Berries harboring the pest and which fell to the ground are a very important source for the re-infestation of next season's coffee (Baker, 1999; Bernal et al., 1999; Bustillo et al., 1999 ) as based on the fact that the CBB continues to reproduce and develop in these fallen berries (Bergamin, 1944a; Salazar et al., 1993). Our data from Western Kenya clearly shows that the coffee berries on the ground are not only the main reservoir of the beetles but also of its predominant parasitoid in East Africa, $P$. nasuta. We therefore hypothesize that the cultural control practice of removing infested coffee berries from the field may greatly affect the performance of $P$. nasuta.

As a parasitoid of immature stages of $C B B$, most of the life cycle of $P$. nasuta occurs within the coffee berries (Hargreaves, 1935; Abraham et al., 1990). In addition, the parasitoid generally attacks CBB when the coffee is close to harvesting (Hargreaves, 1935), and these nearly ripe berries are the main targets of cultural control of H. hampei.

There is ample evidence of positive effects of cultural control on biological control agents in the literature (e.g. Landis et al., 2000; Jonsson et al., 2008). However, negative interactions have received considerably less attention (van Emden and Service, 2004). For instance ploughing can negatively influence biological control of the sugar-beet weevil Bothynoderes punctiventris Germ (Coleoptera: Curculionidae) (van den Bosch and Telford, 1964), and it has been shown that coffee pruning affects natural enemies of the Antestia bug Antestiopsis orbitalis Westwood (H.F. 

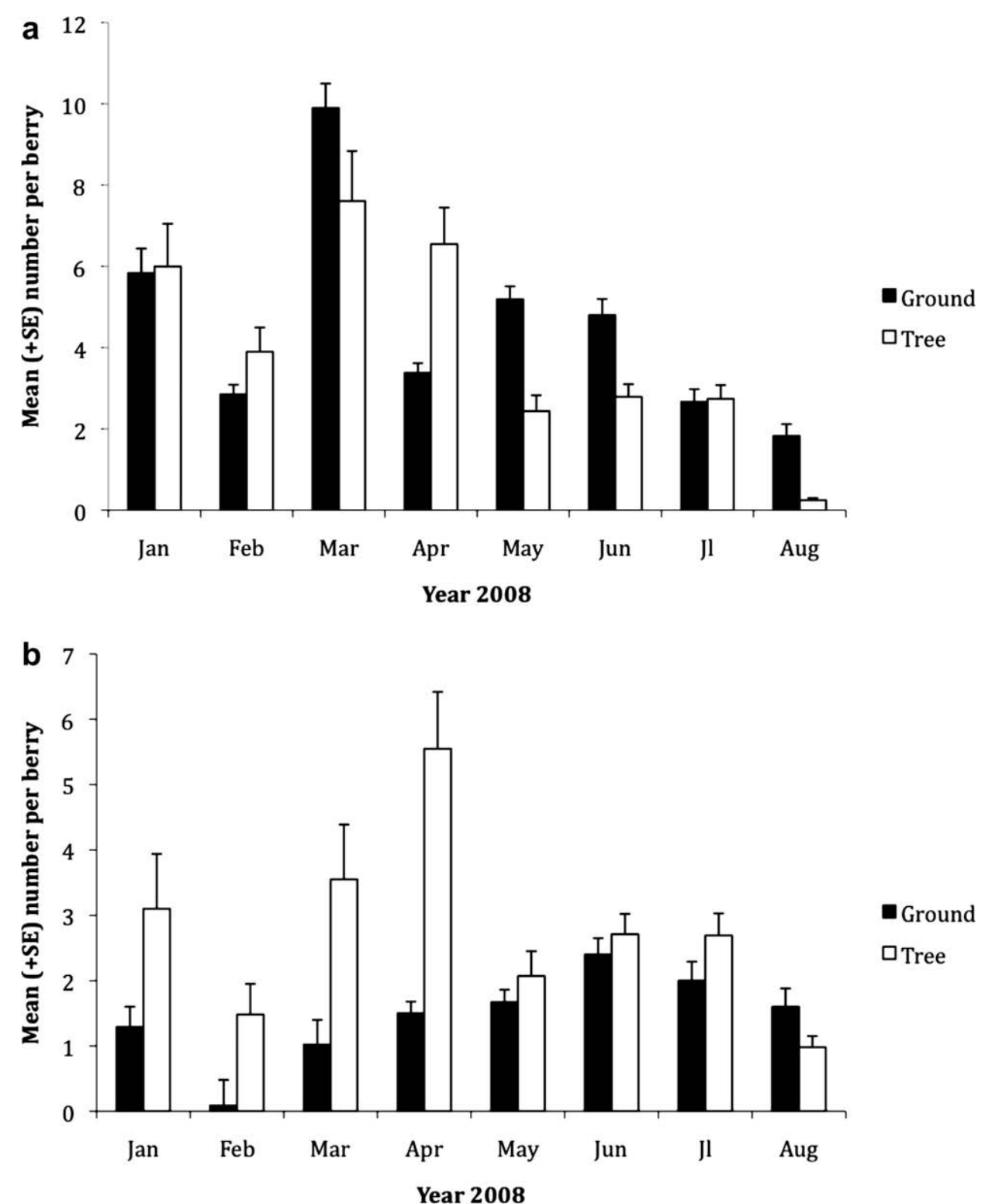

Fig. 5. Mean (+SE) numbers of (a) total Hypothenemus hampei females, and (b) Hypothenemus hampei live females inside coffee berries collected on coffee trees or on the ground over time.

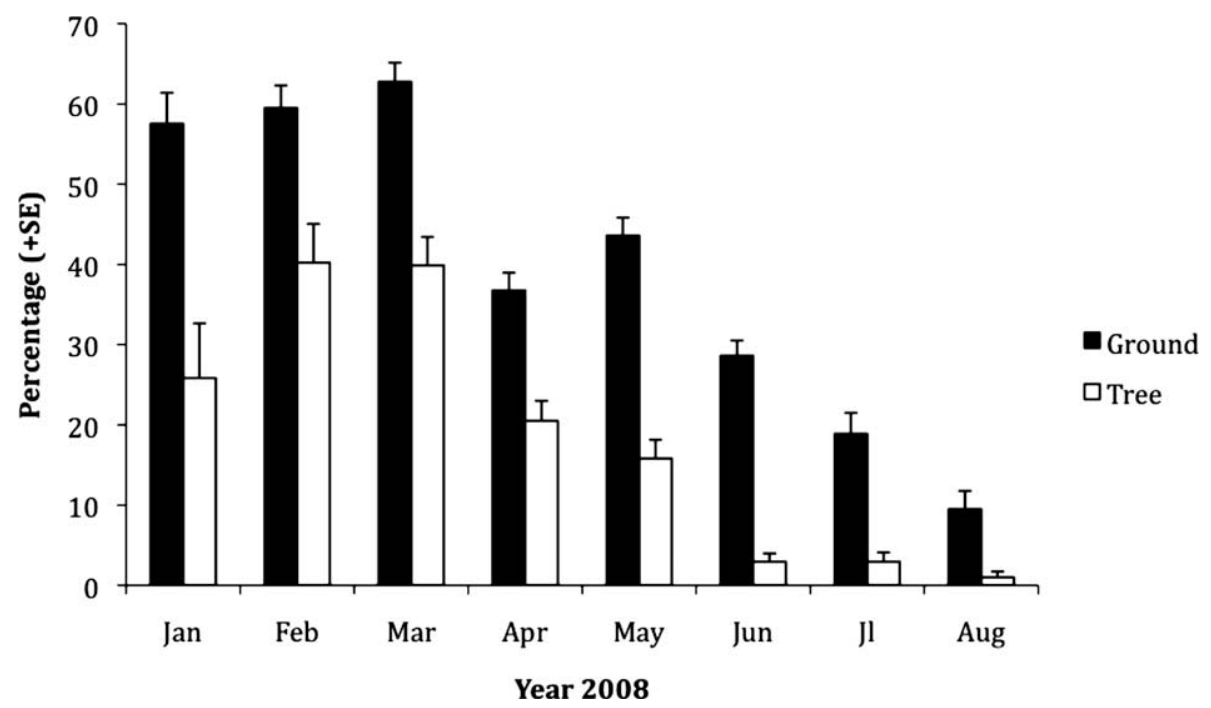

Fig. 6. Percent Hypothenemus hampei adult mortality in coffee berries collected on coffee trees or on the ground over time. 
van Emden, pers. comm.). Yet, a strikingly similar example to CBB and $P$. nasuta has been reported in fruit flies: Purcell et al. (1994) found that the braconid Diachasmimorpha longicaudata (Ashmead), a parasitoid of the Oriental fruit fly Bactrocera dorsalis (Hendel), attacks its hosts in guava plantations primarily in fruits that have fallen to the ground; therefore orchard sanitation seriously affects parasitism rates. An ingenious solution to overcome this problem is a screened-enclosure called the augmentorium (Klungness et al., 2005), in which all infested fruits collected from the field are placed. The screen material used for its construction prevents the escape of tephritid flies emerging from infested fruit, but allows the escape of parasitoid wasps, thus minimizing the negative effects of crop sanitation on natural enemies (Jang et al., 2007). The use of the augmentorium has been shown to be highly efficient in reducing fruit fly populations in the field (Klungness et al., 2005).

Damon and Valle (2002) have reported that the efficacy of C. stephanoderis in Mexico was five times higher when coffee berries containing the wasps were released in the field, as compared to direct release of adult wasps. Thus, we believe that a structure similar to the augmentorium should be tested in coffee plantations in the Americas to harness the full biological control potential of $P$. nasuta. It seems likely that such an approach will result in increased parasitism levels by $P$. nasuta, and lower yield losses due to $\mathrm{CBB}$ infestation.

\section{Acknowledgments}

We are grateful to Prof. Helmut van Emden (University of Reading) and Dr. Sunday Ekesi (icipe) for very helpful suggestions to the manuscript. We thank Mr. Abel O. Mainya from Kisii Coffee Demonstration for kindly providing the coffee berries and for his help during the sampling period. Our most sincere thanks to Geoffrey White, Michael W. Gates, Matthew Buffington, Robert Kula and Allen L. Norrbom at the Systematic Entomology Laboratory (USDA, ARS) for identifying specimens. This research was funded by the German Research Foundation - Deutsche Forschungsgemeinschaft (DFG).

\section{References}

Abraham, Y.J., Moore, D., Godwin, G., 1990. Rearing and aspects of biology of Cephalonomia stephanoderis and Prorops nasuta (Hymenoptera: Bethylidae) parasitoid of the coffee berry borer, Hypothenemus hampei (Coleoptera: Scolytidae). Bulletin of Entomological Research 80, 121-128.

Aristizabal, L.F., Salazar, H.M., Mejia, C.G., 2002. Changes in the adoption of the components of coffee berry borer Hypothenemus hampei (Coleoptera: Scolytidae) integrated management, through participative methodologies. Revista Colombiana de Entomología 28, 153-160.

Baker, P.S., 1999. The Coffee Berry Borer in Colombia. DFID-CENICAFE-CABIBIOSCIENCE, Chinchiná, Colombia.

Barrera, J.F., Baker, P.S., Valenzuela, J.E., Schwarz, A., 1990. Introducción de dos especies de parasitoides Africanos a México para el control biológico de la broca del café Hypothenemus hampei (Ferrari) (Coleoptera: Scolytidae). Folia Entomológica Mexicana 79, 245-247.

Batchelor, T.P., Hardy, I.C.W., Barrera, J.F., 2006. Interactions among bethylid parasitoid species attacking the coffee berry borer, Hypothenemus hampei (Coleoptera: Scolytidae). Biological Control 36, 106-118.

Batchelor, T.P., Hardy, I.C.W., Pérez-Lachaud, G., 2005. Insect gladiators II: competitive interactions within and between bethylid parasitoids species of the coffee berry borer Hypothenemus hampei (Coleoptera: Scolytidae). Biological Control 32, 194-202.

Benavides, P., Bustillo, A., Montoya, E.C., Cardenas, R., Mejia, C., 2002. Participation of cultural, chemical and biological control in the management of the coffee berry borer. Revista Colombiana de Entomología 28, 161-165.

Bergamin, J., 1944a. Sombreamento e broca. Revista do Departamento Nacional do Café 12, 1009-1014.

Bergamin, J., 1944b. A broca do café no Brasil. Boletim da Superintendencia dos Servicos do Café (São Paulo) 33, 21-22.

Bernal, M.G., Bustillo, A.E., Chavez, B., Benavides, P., 1999. Effect of Beauveria bassiana and Metarhizium anisopliae on Hypothenemus hampei (Coleoptera: Scolytidae) populations emerging from fallen coffee fruits in the soil. Revista Colombiana de Entomología 25, 11-16.
Borbón-Martinez, M.O., 1989. Bio-écologie d'un ravageur des baies de caféier Hypothenemus hampei Ferr. (Coleoptera: Scolytidae) et de ses parasitoides au Togo. PhD thesis, University of Toulouse, France.

Bustillo, A.E., Bernal, M.G., Benavides, P., Chavez, B., 1999. Dynamics of Beauveria bassiana and Metarhizium anisopliae infecting Hypothenemus hampei (Coleoptera: Scolytidae) populations emerging from fallen coffee berries. Florida Entomologist 82, 491-498.

Bustillo, A.E., Cardenas, R., Villalba, D., Benavides, P., Orozco, J., Posada, F.J., 1998. Manejo integrado de la broca del café Hypothenemus hampei (Ferrari) en Colombia. CENICAFÉ, Chinchiná, Colombia.

Damon, A., 2000. A review of the biology and control of the coffee berry borer Hypothenemus hampei (Coleoptera: Scolytidae). Bulletin of Entomological Research 90, 453-465.

Damon, A., Valle, J., 2002. Comparison of two release techniques of the use of Cephalonomia stephanoderis (Hymenoptera: Bethylidae) to control the coffee berry borer Hypothenemus hampei (Coleoptera: Scolytidae) in Soconuco, South Eastern Mexico. Biological Control 24, 117-127.

Duque, O.H., Baker, P.S., 2003. Devouring Profit: The Socio-economics of Coffee Berry Borer IPM. The Commodities Press, CABI/CENICAFE.

Hargreaves, H., 1926. Notes on the coffee berry borer (Stephanoderes hampei, Ferr.) in Uganda. Uganda Bulletin of Entomological Research 16, 347-354.

Hargreaves, H., 1935. Stephanoderis hampei Ferr., coffee berry borer, in Uganda. The East African Agricultural Journal 1, 218-224.

Hempel, A.A., 1934. Prorops nasuta Waterston no Brasil. Arquivos do Instituto Biologico 5, 197-212.

Infante, F., 1998. Biological control of Hypothenemus hampei (Coleoptera: Scolytidae) in Mexico, using the parasitoid Prorops nasuta (Hymenoptera: Bethylidae). PhD thesis. Imperial College, UK, p. 173.

Infante, F., Mumford, J., Mendez, I., 2001. Non-recovery of Prorops nasuta (Hymenoptera: Bethylidae), an imported parasitoid of the coffee berry borer (Coleoptera: Scolytidae) in Mexico. Southwestern Entomologist 26, 159-163.

Infante, F., Mumford, J., Baker, P., 2005. Life history studies of Prorops nasuta, a parasitoid of the coffee berry borer. BioControl 50, 259-270.

Jang, E.B., Klungness, L.M., Mcquate, G.T., 2007. Extension of the use of Augmentoria for sanitation in a cropping system susceptible to the alien tephritid fruit flies (Diptera:Tephritidae) in Hawaii. Journal of Applied Science and Environmental Management 11, 239-248.

Jaramillo, J., Borgemeister, C., Baker, P.S., 2006. Coffee berry borer Hypothenemus hampei (Coleoptera: Curculionidae): searching for sustainable control strategies. Bulletin of Entomological Research 96, 223-233.

Jaramillo, J., Chabi-Olaye, A., Poehling, H.M., Kamonjo, Ch., Borgemeister, C., 2009 Development of a new laboratory production technique for coffee berry borer Hypothenemus hampei (Ferrari) (Coleoptera: Curculionidae, Scolytinae), using fresh coffee berries. Entomologia, Experimentalis et Applicata, in press.

Jaramillo, J., Vega, F.E., 2009. Aphanogmus sp. (Hymenoptera: Ceraphronidae): a hyperparasitoid of the coffee berry borer parasitoid Prorops nasuta Waterston (Hymenoptera: Bethylidae) in Kenya. Biocontrol Science and Technology, in press.

Jonsson, M., Wratten, S.D., Landis, D.A., Gurr, G.M., 2008. Recent advances in conservation biological control of arthropods by arthropods. Biological Control $45,172-175$.

Klungness, L.M., Jang, E.B., Mau, R.F.L., Vargas, R.I., Sugano, J.S., Fujitani, E., 2005. New sanitation techniques for controlling tephritid fruit flies (Diptera: Tephritidae) in Hawaii. Journal of Applied Science and Environmental Management 9, 5-14.

Landis, D.A., Wratten, S.D., Gurr, G.M., 2000. Habitat management to conserve natural enemies of arthropod pests in agriculture. Annual Review of Entomology 45, 175-201.

Le Pelley, R.H., 1973. Coffee insects. Annual Review of Entomology 18, 121-142.

Maldonado, C.E., 2007. Variabilidad genética y evaluación biológica del parasitoide Prorops nasuta Waterston en Colombia. University of Pamplona, Colombia. M.Sc., thesis, p. 71.

Murphy, S.T., Day R., Orozco, J., Kucel P., 2001. Investigations into the use of Heterospilus coffeicola for the biological control of the coffee berry borer in Latin America and Africa. Unpublished report for the period Nov 2000-July 2001, CABI Commodities, Ascot, UK, p. 13.

OILB, 1971. Liste d'identification des entomophages 8. OILB, Genève.

Pérez-Lachaud, G., Hardy, I.C.W., Lachaud, J.P., 2002. Insect gladiators: competitive interactions between three species of bethylid wasps attacking the coffee berry borer, Hypothenemus hampei (Coleoptera: Scolytidae). Biological Control 25, 231-238.

Pérez-Lachaud, G., Batchelor, T.P., Hardy, I.C.W., 2004. Wasp eat wasp: facultative hyperparasitism and intra-guild predation by bethylid wasps. Biological Control 30, 149-155.

Pérez, J., Infante, F., Vega, F.E., 2005. Does the coffee berry borer (Coleoptera: Scolytidae) have mutualistic fungi? Annals of the Entomological Society of America 98, 483-490.

Perfecto, I., Mas, A., Dietsch, T., Vandermeer, J., 2003. Conservation of biodiversity in coffee agroecosystems: a tri-taxa comparison in Southern Mexico. Biodiversity and Conservation 12, 1239-1252.

Purcell, M.F., Jackson, C.G., Long, J.P., Batchelor, M.A., 1994. Influence of guava ripening on parasitism of the oriental fruit fly, Bactrocera dorsalis (Hendel) (Diptera: Tephritidae), by Diachasmimorpha longicaudata (Ashmead) (Hymenoptera: Braconidae) and other parasitoids. Biological Control 4, 396-403.

Quintero, C., Bustillo, A.E., Benavides, M.P., Chaves, C.B., 1998. Evidencias del establecimiento de Cephalonomia stephanoderis y Prorops nasuta (Hymenoptera: 
Bethylidae) en cafetales del departamento de Nariño, Colombia. Revista Colombiana de Entomología 24, 141-147.

Richter, A., Klein, A.M., Tscharntke, T., Tylianakis, J.M., 2007. Abandonement of coffee agroforests increases insect abundance and diversity. Agroforestry Systems 69, 175-182.

Salazar, M.R., Chaves, B., Riaño, N., Arcila, J., Jaramillo, R.A., 1993. Crecimiento y desarrollo del fruto del café Coffea arabica L. var. Colombia. Revista Cenicafé 45, 41-50.

SAS Institute Inc., 1999. SAS/STAT User's Guide. SAS Institute Inc., Cary, North Carolina.

Shannon, C.E., 1948. A mathematical theory of communication. The Bell System Technical Journal 27, 379-423 and 623-656.

Ticheler, J., 1961. Etude analytique de lépidémiologie du scolyte des graines de café Stephanoderis hampei Ferr. en Cõte d́lvoire. Mededelingen Landbouwhogeschool Wageningen 61, 1-49. van den Bosch, R., Telford, A.D., 1964. Environmental modification and biological control. In: DeBach, P. (Ed.), Biological Control of Insect Pests and Weeds. Chapman and Hall, London, UK, pp. 459-487.

van Driesche, R.G., 1983. Meaning of "percent parasitism" in studies of insect parasitoids. Environmental Entomolgy 12, 1611-1622.

van Emden, H.F., Service, M.W., 2004. Pest Vector Control. Cambridge University Press, UK.

Vega, F.E., 2004. Coffee berry borer Hypothenemus hampei (Ferrari) (Coleoptera: Scolytidae). In: Capinera, J.L. (Ed.), Encyclopedia of Entomology, vol. 1. Kluwer Academic Publishers, Dordrecht, The Netherlands, pp. 575-576.

Vega, F.E., Mercadier, G., Damon, A., Kirk, A., 1999. Natural enemies of the coffee berry borer, Hypothenemus hampei (Ferrari) (Coleoptera: Scolytidae) in Togo and Cõte d'Ivoire, and other insects associated with coffee beans. African Entomology 7, 243-248. 